in Paris more than six months ago. But because it is so strongly critical, it has been impossible to persuade the Italian authorities to turn up for the meeting. The situation has undoubtedly been further complicated by the present election campaign in Italy, and the staff at OECD are now resigned to waiting at least until the election is over before the report can be discussed.

The principal criticism seems to have been directed at the university system in Italy-rigid, hierarchical and inflexible, as an OECD executive described it this week. (With the hindsight of the last two weeks, this is a criticism which might have been directed equally accurately at the rest of Europe as well.) These criticisms echo those of Professor Joseph Ben-David, in his report Fundamental Research and the Universities, prepared some months ago for the OECD. The rigidity of the system -one professor, one chair and one faculty for each subject-combined with a lack of mobility among research workers, has meant, according to Professor Ben-David, that universities in Europe have fallen behind those in the United States, either as centres of scientific discovery or as generators of industrial change.

The report also criticizes the organization and scale of research and development in Italian industry. Figures already published by the OECD provide the basis for this charge. In 1963, Italy spent only 0.6 per cent of its GNP on research and development, against $2 \cdot 3$ per cent for the UK, $3 \cdot 4$ per cent for the USA, 1.9 per cent for the Netherlands and 1.5 per cent for Sweden. Even Ireland, not generally thought of as an industrialized country, spent nearly as much as a proportion of GNP as Italy. In fundamental research, Italy spent less than a third as much as France $(\$ 70 \cdot 6$ million against $\$ 221$ million), and less than the Netherlands ( $\$ 81.5$ million). This in turn is reflected by a greater tendency to import technology. Italy's bill for patents, licences and technological know-how imported from abroad was $\$ 135$ million in 1963, against $\$ 130$ million for Japan. It was exceeded only by West Germany, with $\$ 150.9$ million (a 1964 figure).

But it is in the production of qualified manpower that the comparison is least favourable to Italy. First degree graduates in technology represent only 0.4 per cent of the age group between 20 and 24, and only another 0.5 per cent of the age group qualify as scientists. The comparable figures for the United Kingdom (which did surprisingly well in the survey) were 2.9 and 1.7 per cent, and for France the figures were 1.5 and $2 \cdot 4$ per cent. Graduates in all subjects represent $3 \cdot 5$ per cent of the age group in Italy, 21 per cent in the United States, and $\mathbf{1 0 . 5}$ per cent in the UK.

The Italian authorities have complained that the report makes use of old statistics, collected in 1963 . But it is unlikely that newer figures, which may be incorporated into the final report, would make the situation look any happier. What is most surprising is that, despite Italy's neglect of higher education and scientific research, the Italian economy has had a more successful time than that of, say, Britain. What has to be remembered is that Italy is itself divided almost as sharply between an industrialized north and an underdeveloped south as it is from other countries in Europe. This makes the figures more easy to understand, although it does not remove the need for concern. The workers at the CNR did well to turn it into a political issue.

\section{More Negotiation for Intelsat}

CETS (the European Conference for Satellite Communications), which was formed in 1963 to provide a united European front at the negotiations with the United States leading to the 5-year interim world communications satellite agreement (Intelsat) which was finally signed in 1964, is now engaged in formulating its position for next year's negotiations for a new deal for Intelsat. Next year's revised arrangements are intended to produce a permanent organization and a plan for long-term operations-the working of the present agreement is far from satisfactory. There are three main negotiation objectives for CETS. First, Intelsat is effectively an American monopoly: it is hoped to change this. Second, Comsat, the American Communications Satellite Corporation, is in an anomalous position, being at the same time the managing body for Intelsat and an American commercial company; the object is to obtain genuine internationalization of Intelsat management. Third, there is room for a much better contract position for European firms than at present, and CETS wants to get it.

The European countries together shoulder about 30 per cent of Intelsat costs, yet their share of the international contracts placed by the organization amounts to only 4 per cent. Contracts in the so-called "space sector" alone are open to international competition; ground installations are the responsibility of the individual countries where they are located. It is precisely in the field of satellite construction, satellite sub-systems, onboard power supplies and such things that European tenders have done badly, in part, of course, because they lack the experience of their American competitors. It is a cogent argument of CETS advisers that the inequality will not be rectified without more direct European participation in the launching and designing of satellites. This was an attraction of the CETS project for the Eurovision satellite (Nature, 21\%, 1089; 1968) which the British Government has now rejected-apart from its promise of an independent alternative to the Intolsat service which may not fully accommodate Europe's specifically regional needs.

The CETS committee of deputies held a meeting in London on May 16 and 17 to hammer out the lines of approach for next year's Intelsat negotiations (CETS deputies are junior government ministers). Although a coherent joint policy document is required by the end of the year, they found themselves unable to make progress in the face of the British Government's negative statement on the CETS proposal. The resulting disarray has caused a postponement of the Bonn meeting of the European Space Conference from July till October or so.

Britain's views of ELDO's future usefulness and the virtue of the Eurovision satellite are in a minority, but if the other leading European space nations led by France and Germany go on without Britain, as they are inclined to do, there are a number of points to be settled and agreed. These include the cost of the Blue Streak booster which is the basis of the ELDO launcher and which is understood to be available without British participation; the cost of using the Spadeadam test facilities which "prove" individual Blue Streaks before shipment for launching, and various other pieces of information on which poliey decisions involving finance must rest. 